\title{
Over-research and ethics dumping in international archaeology \\ Nghiên cứu mang tính lối mòn và sự tha hóa về mặt đạo đức trong khảo cổ học quốc tế

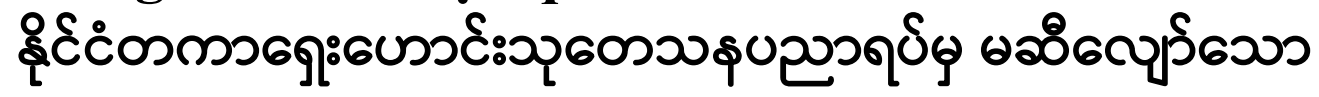

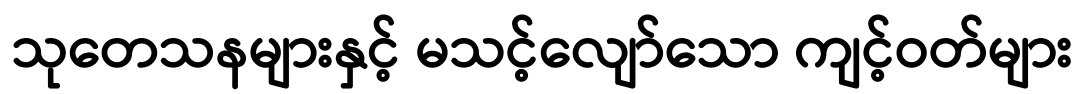

\author{
Ben Marwick ${ }^{1}$, Pham Thanh Son ${ }^{2}$ and May \\ $\mathrm{Su} \mathrm{Ko}{ }^{3}$ \\ ${ }^{1}$ Department of Anthropology, University of \\ Washington, USA \\ ${ }^{2}$ Institute of Archaeology, Hanoi, Vietnam \\ ${ }^{3}$ Department of Archaeology, University of Yangon, \\ Myanmar
}

Correspondence: bmarwick@uw.edu

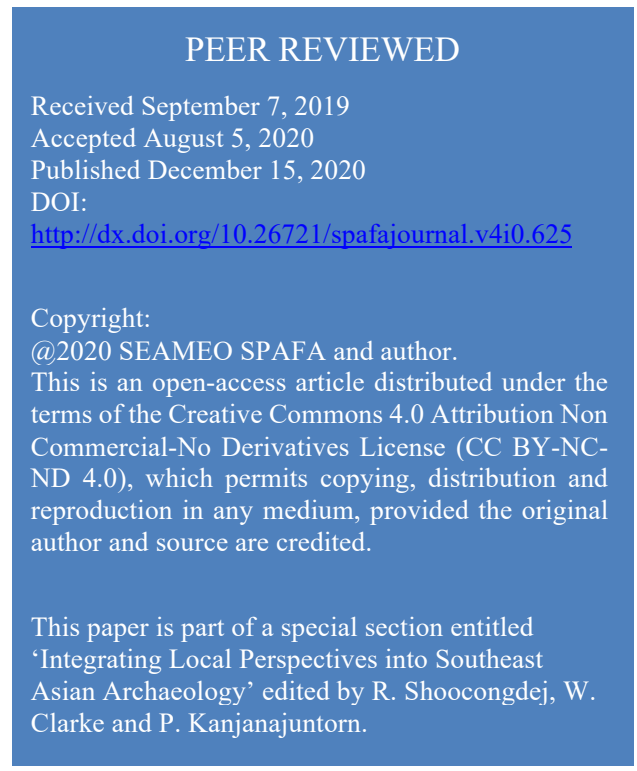

\begin{abstract}
Among public health researchers two ethical concerns have recently stimulated discussion: "overresearch" and "ethics dumping". Over-research refers to a situation where the host community are not benefiting from research activity conducted by outsiders. Ethics dumping refers to doing research deemed unethical in a researcher's home country in a foreign setting with laxer ethical rules. We briefly review the origins of these terms and explore their relevance for archaeology, with special consideration of Southeast Asia. To minimize over-research and ethics dumping in archaeology we propose some modest, specific activities that should be possible for all archaeologists to do to increase the benefit of their research to local communities, and to ensure their work is consistent with international ethical standards.
\end{abstract}

Tóm tắt: "Trong những điểm chung về tính lành mạnh của các nhà nghiên cứu, hai mối quan tâm về mặt đạo đức gần đây đã thúc đẩy thảo luận về: "nghiên cứu mang tính lối mòn và sự tha hóa về mặt đạo đức". Nghiên cứu mang tính lối mòn ám chỉ tới một trạng thái mà cộng đồng sở tại không được hưởng lợi từ các hoạt động nghiên cứu đã tiến hành bởi người ngoài. Sự tha hóa về đạo đức ám chỉ tới việc thực hiện nghiên cứu phi đạo đức không theo một số quy tắc đạo đức ở chính quê hương của mỗi nhà nghiên cứu khi thực hiện nghiên cứu ở bên ngoài quốc gia của họ vì các quy tắc lỏng lẻo về mặt đạo đức. Chúng tôi sẽ xem xét ngắn gọn một số căn nguyên của các thuật ngữ này và tìm hiểu sự liên quan của chúng đối với khảo cổ học, bằng cách xem xét cụ thể ở Đông Nam Á. Để có thể giảm thiểu việc nghiên cứu mang tính lối mòn và sự tha hóa về mặt đạo đức, chúng tôi đề xuất những hành động cụ thể và trong chừng mực mà các nhà khảo cổ học có thể thực hiện nhằm gia 
tăng lợi ích nghiên cứu của họ đối với các cộng đồng sở tại, và cũng là để củng cố việc làm của họ sao cho phù hợp với các tiêu chuẩn đạo đức quốc tế.

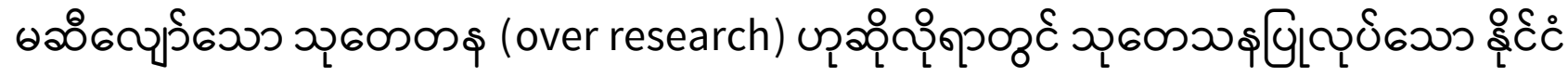

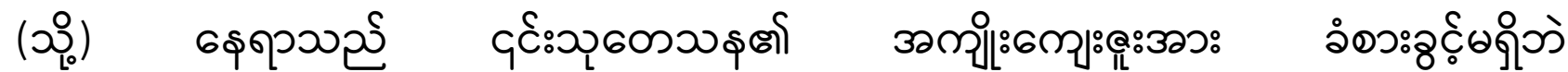

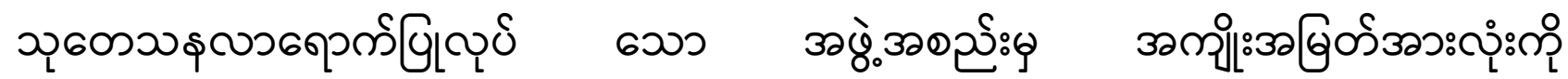

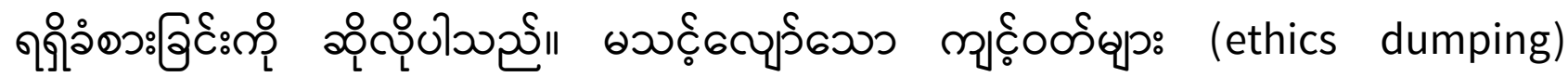

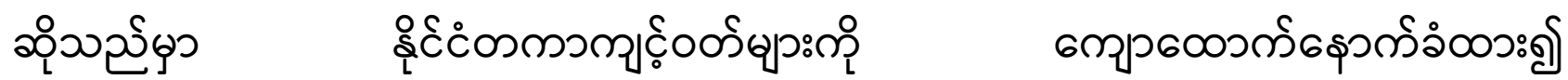

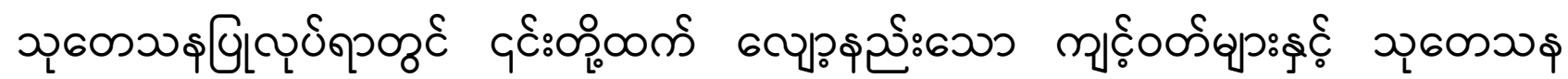

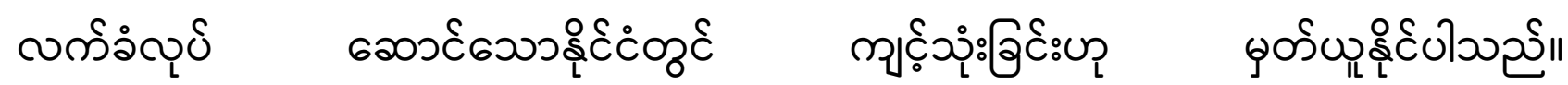

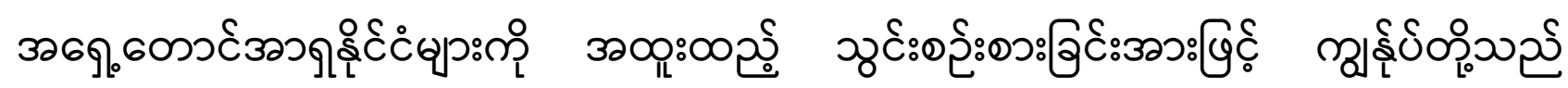

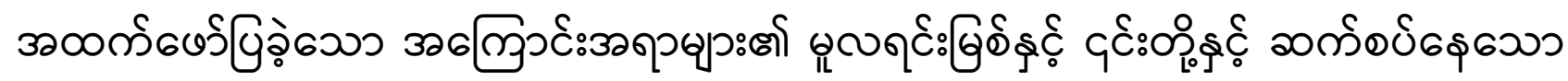
6్:6uدว

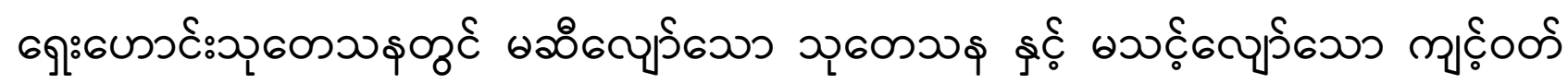

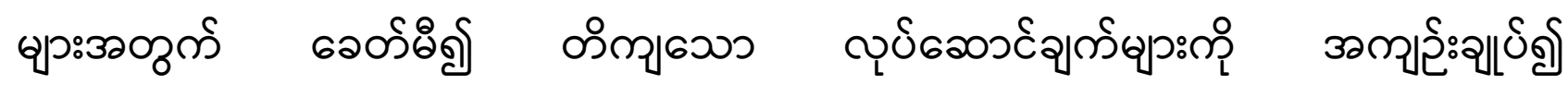

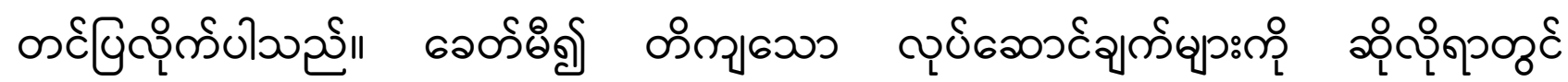

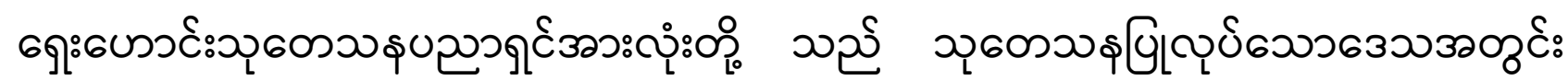

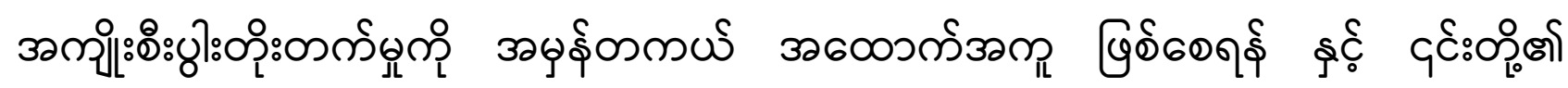

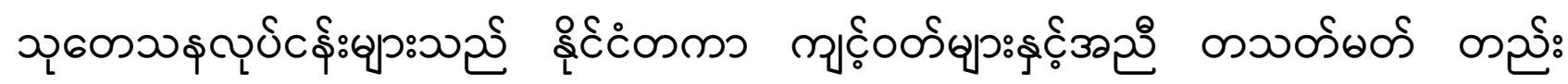

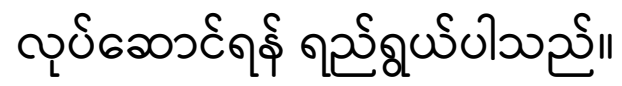

Keywords: Archaeology; Southeast Asia; Ethics; Over-research; Ethics dumping | Khảo cổ học; Đông Nam

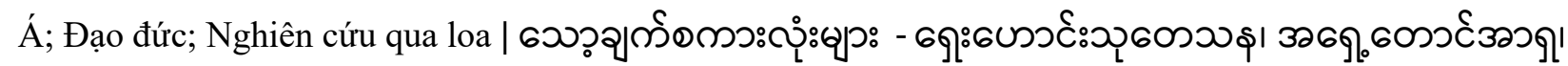

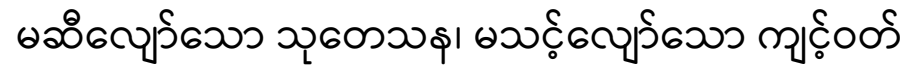

\section{Introduction}

In this paper we introduce two concepts, "over-research" and "ethics dumping" that have emerged in some biomedical research communities outside of archaeology. These concepts give us new perspectives to reflect on the integrity of our practice. The focus here is on the relationship between archaeologists and allied researchers (e.g. social scientists, geoscientists) from developed nations 
and their research collaborators in less-developed nations and regions, especially Southeast Asia. To date, many of the narratives on this relationship have been framed around colonialism. While many of these still shape our interactions in substantial ways, we believe that they may be losing their relevance and impact as the colonial periods recede into the past. Another reason for the declining relevance of colonialism is that our interactions are not as much defined by issues of political and national identity as they were in the past (Glover 1993, 2001), but by research and funding priorities, and career advancement requirements.

This paper will describe over-research and ethics dumping, and review how these concepts are manifest in other research communities. We will extend the lessons extracted from this literature review to identify what archaeologists and cultural heritage managers can learn, and how we can benefit. The aim of this paper is to introduce over-research and ethics dumping as cautionary tales to motivate a more equitable distribution of the benefits of research work, and more harmonious relationships among stakeholders, in archaeology and cultural heritage management in Southeast Asia. To conclude, we will sketch a few recommendations to avoid or mitigate these problems in archaeology.

\section{Over-research}

At a first glance, over-research might appear to refer to situations when many people are working on similar problems to the point where we perceive few novel results are possible. Because it depends on community perception, it is difficult to identify specific metrics for over-research. In Southeast Asia, where the number of archaeologists is relatively small, this common sense of overresearch is generally a minor concern, relative to more intensively researched regions, for example, western Europe, southwest Asia or southern Africa. Whitaker (1963) develops this concept of overresearch further, defining it as a condition when the research questions being worked on are so remote from any practical benefit they are of very limited interest beyond the academy.

This is an evergreen concern for archaeology (Childe 1933) because the discipline will never directly generate immediate, tangible benefits such as curing an epidemic or eradicating poverty. Our problem is that, with a few exceptions, archaeologists rarely produce a pragmatic general benefit to the public because we rarely encounter a narrow neck of causality (Abbott 2004), where archaeological work is part of a small number of mechanisms that can be identified and controlled in the scheme of causes of phenomena of broad importance to the public. Instead, in our case we might imagine it improving people's quality of life by preserving their landscape (if a development project was rerouted when an archaeological site was found). Another pragmatic benefit is the generation of meaning, including the production of history and the ending of historical silence for communities that have been excluded from written histories (Mrozowski 2012). In regions where a European colonial presence was extensive, such as the United States and Australia, archaeology has been important for providing evidence for Indigenous groups who are seeking recognition, compensation, and autonomy from federal governments (Lightfoot et al. 2013; Lilley 2000). In other cases, archaeology can provide local and Indigenous communities with an increased sense of belonging, community legitimacy and familiarity with the place they live by showing continuity of lifeways from prehistory into the present (Marwick et al. 2013).

This expanded sense of 'over-research' as 'limited practical benefit' is one that will be familiar to most archaeologists when reflecting on the relevance of the discipline. This sense of the phrase seems primarily to be used pejoratively, implying that too much research has been conducted, and not enough has been translated into social benefit, or that the social benefits are not widely 
appreciated. However, what constitutes 'too much' research in a more specific, local sense? And, what is it about 'over-research' that is ethically bad? In most cases of its use, the term is not interrogated, but used with its meaning taken for granted. We can get some additional insights into how to address these questions from public health research, where over-research has been documented to an extreme that might be difficult to imagine in archaeology.

The Shatila Palestinian refugee camp in Beirut, Lebanon, is a striking example of over-research in public health. It was originally established in 1949 to accommodate Palestinian refugees following the establishment of the state of Israel in 1948. It is now a densely populated neighbourhood of multistorey concrete buildings in a single square kilometer, home to more than 10,000 refugees (Sukarieh and Tannock 2013). Because of its eventful, tragic history, and its convenient location between downtown Beirut and the Beirut international airport, international researchers flock to Shatila to track the effects of prolonged refugee status and cultural isolation on the community. Hundreds of researchers have visited and interviewed the residents, to the point where some local groups are calling for a stop to research being done in the camps (Sukarieh and Tannock 2013).

Sukarieh and Tannock have interviewed residents to investigate why they want to stop research. They found that residents' expectations about the importance of research have diminished over many years of failing to see any benefits. Sukarieh and Tannock's investigation of this context of over-research revealed three concerns. First, poor research quality indicated by researchers with incomplete background knowledge and repeating past work. Second, researchers fail to share their conclusions and data back to the community that provided them, which they categorise as a failure of the researcher's ethics. Third, residents are suspicious of the political agendas of researchers, particularly those coming from countries with governments that are pro-Israel and anti-Muslim, such as the USA and the UK. The weak relationship between research activity and improvement in the residents' quality of life leads many residents to conclude that the research is being used by politicians to control and suppress them and diminish their political issues.

The example of Shatila conveys a sense of over-research as a situation where repeated engagements between researchers and local communities do not lead to any experience of positive change for the local community (Clark 2008). To understand how this might be relevant to archaeologists, we will draw on Koen et al. (2017) who have provided an extensive analysis of how public health researchers perceive the concept of over-research. They analysed concerns about over-research by interviewing 24 HIV prevention researchers at two sites of HIV-prevention studies in South Africa. They found three themes in how these researchers understood the concept of over-research, and we use these here to generate questions about archaeology and over-research.

\section{Social values}

Over-research implies that socially important concerns of the local community are being neglected. In biomedical fields, social value is defined as the 'relevance for understanding or intervening on a significant health problem or because of its expected contribution to research likely to promote individual or public health' (World Health Organization and Council for International Organizations of Medical Sciences 2016). There are a wide range of definitions of the social value of archaeology and related areas such as heritage and museum studies. European archaeologists have been especially active in surveying the communities they work with to identify the social values of archaeology. Van den Dries et al. (2015) reported on surveys of residents living near their Tell Balata project (Palestine) and Oss (Netherlands) and found that the social values of archaeology include strengthening social relationships and interactions through shared experiences, 
enhancing social inclusion or integration of people into civil society, and adding to people's sense of belonging to their place of residence. The NEARCH (New Scenarios for a Community-involved Archaeology) project surveyed 4,516 people in nine European countries to identify public perceptions of archaeology and archaeological heritage, and public expectations of archaeology (Kajda et al. 2018). They found that archaeology contributes value to society through its legitimization of one's presence in a place, what it contributes to understanding our place in the world, and how it helps to make better preparations for the future. In Southeast Asia we are yet to see large scale survey studies into the social value of archaeology. To date, we have Lape and Hert's (2011) report on a survey of public attitudes regarding archaeology among 98 community members in Timor Leste. They found that the community valued archaeology, but they did not collect data on social values.

Taking a more reflexive approach, Holtorf (2018) contemplates how the management of archaeological sites at risk of destruction can contribute to a local community's own cultural resilience. Archaeology contributes social value through risk preparedness by inspiring people to embrace uncertainty and absorb adversity in times of change. Perry (2019) similarly argues for social values of archaeology at personal and community levels. Perry proposes that archaeology contributes to personal restoration and transformation, family bonding and community building, and supporting and identifying concerns to protect what one perceives as important. Perry claims these qualities lead to the cultivation of an ethic of generosity and considerate action, enhancing social bonding and mutual respect, and ultimately a role for archaeology in contributing to greater civic welfare.

From this wide variety of social values, we can generalise that a failure to create social value results from a failure to appropriately disseminate findings to relevant stakeholders in order to facilitate the translation of research results into policy and practice. For public health researchers, translation should result in positive public health outcomes. But for archaeologists, it is less obvious how we can identify a positive outcome when attempting to realise the social value of our work. How do we know how the communities we work with will find value in archaeology? Do we know who our stakeholders are and how do we ensure that we return our findings and data to them in a meaningful way? What impact can our archaeological research results have on planning, policy, social practice, and civic welfare? These questions are difficult to give generic answers to because of the great variation between one community to another. The most parsimonious approach is direct consultation between archaeologists and the communities that we work with, to learn and negotiate where value resides, and how it can be given in an authentic way. A complication to this process of negotiation is described by González-Ruibal et al. (2018) who note that archaeologists often hold an idealised notion of communities as a 'perfect subject', holding their heritage as an intrinsically valuable part of their identity. González-Ruibal (2019) reports on ethnographic research showing that local community members do not always concur with archaeologists' progressive social values, and do not always revere their past or their past's materiality, or feel a strong attachment to the material traces in a way that archaeologists would prefer. This highlights the need for directly engaging with local communities to identify the most beneficial modes of engagement, provocation and education that archaeology can provide. We must be open to the possibility that western European notions of the enchantment of archaeology as a social value may not resonate with the communities that we work with, and be responsive to their preferences, even indifference (González-Ruibal 2019). 


\section{Scientific validity}

This theme refers to a concern about collaboration between researchers and the coordination of multiple concurrent studies with one another, in order to ensure scientific integrity, maximum benefit, and minimal fatiguing of local community members involved in the research. It also refers to concerns about researchers taking patriarchal 'ownership' of a research resource (e.g. region or site) under the guise of protecting scientific validity, preventing other researchers from accessing the resource.

The international community of archaeologists is relatively small, relative to other disciplines, and in Southeast Asia, especially small, so issues of coordination are not highly complex and, these issues are usually probably minor. More of a concern in Southeast Asia is perhaps the concept of ownership, where some researchers and groups can occupy a site or region for decades. This restrictive ownership is evident at multiple levels, for example some local archaeologists may be prevented from accessing by more senior local archaeologists.

\section{Risks, benefits and a favorable risk-benefit ratio}

This theme relates to concerns that research fails to benefit participants and communities in ways they can recognise; that benefits to participants and communities were minimal and unfair in relation to benefits to other stakeholders, such as the researchers themselves. A related concern is about inequitable distribution of benefits between researchers and communities. For archaeologists this is a substantial concern. We don't often think of archaeology as having immediate, direct, material benefits to local communities. So this raises the question of how we ought to be benefitting the communities that we work with? Among stakeholders, we can see that in some cases the researcher from the developed country might benefit greatly from a research activity, such as getting a $\mathrm{PhD}$ or publications that might advance their career. But what are the benefits to their local collaborators? What is the ratio of international archaeologists getting PhDs to local archaeologists getting $\mathrm{PhDs}$ from the same field work or working on the same site? How does a per diem collected by a local scholar compare to a $\mathrm{PhD}$ degree obtained by the visiting researcher? Career progression in developing countries is often defined by different metrics to the US, Europe, the UK and Australia, how can we be sure we offer something equivalent to our local counterparts?

\section{How to reduce the risk of over-research in archaeology?}

Cross-cutting these three themes are three broader issues. First, over-research is characterised by different perspectives on what constitutes fair benefits, different understandings about researcher roles and obligations, and different levels of understanding and research literacy between researchers and the members of the communities they work with. Second, over-research is fundamentally a concern about the relationships between stakeholders involved in research. Third, over-research is seen as synonymous with exploitation, where international scholars use their relationships with local scholars, community members, and other resources unfairly for their own advantage. These issues translate easily into the world of Southeast Asian archaeology. They raise questions about how the goals of archaeologists from developed countries align with the goals of archaeologists and local communities in the host countries. This alignment can be especially poor when visiting archaeologists come from research-focused institutions, such as some large Western universities, while local archaeologists are based at governmental organisations focused on heritage management and working with substantially smaller budgets. There are substantial practical and systemic obstacles to perfect equity in the distribution of benefits from research activities. The difference in the organization of universities and processes for public administration from country 
to country leads to different incentives and expectations about what the ideal benefits from research should be.

The risks of over-research need to be prominent in our training and discussions about the politics and ethics of archaeological research. The solution is not simply to take the pressure off one area by moving on to find other, less-researched communities and locations elsewhere. This cannot be a remedy because the typical extractive models of university-based research make the problem of over-research a lurking concern regardless of past work at a location. Part of the solution must be in-depth and sensitive discussions with local communities about what they expect and require from archaeological research. These discussions might reveal that research outcomes that are designed to result in scholarly contributions are not, by themselves, enough to sustain positive relationships with local communities. For example, increasing the opportunities for involvement in the research process by giving community members more active roles in the production and analysis of data, improving mechanisms of feedback and dissemination, or even developing the research skills of community members may help to ameliorate the risks of over-research (Clark 2008). Making our research data openly and easily available (without the need for a request) is also an important, concrete step here (Marwick and Birch 2018). That said, over-research will not be entirely solved by more engaging, enticing or empowering methods. Alternative archaeological research models such as community-based (Atalay 2012; Schaepe et al. 2017) and Indigenous archaeology (Atalay et al. 2016; May et al. 2017; Watkins 2001) still bring risks of over-research (cf. Goldstein 2000). While these are vital improvements and additions to traditional archaeological research practice, they are not a panacea to issues that afflict marginalised and impoverished communities (cf. Pyburn and Wilk 2000). Authentic engagement with local community issues sometimes means that no new research at all is the most appropriate management of the risks of over-research.

\section{Ethics dumping}

In our discussion of over-research at the Shatila camp, we noted that one of the concerns about over-research was the researchers' ethics. In that specific case the ethical concern was about wasteful, duplicative research that indicated a failure by some researchers to do sufficient background work to establish what had already been done. But there are broader ethical concerns emerging from the situation where researchers from a developed country come to work with communities in less developed contexts. In the public health research community, many of these concerns are captured in the concept of 'ethics dumping'. This phrase was coined by the European Commission in 2013, and at its simplest, it refers to doing research deemed unethical in a researcher's home country in a foreign setting with laxer ethical rules (Schroeder et al. 2018). While ethics dumping can apply to any kind of research, it is most serious and most often discussed in health-related and biological contexts where there are international agreements and frameworks and international institutions monitoring their application or enforcement (Floridi 2019). Although archaeology has international agreements and oversight organisations relating to looting and illegal export of artefacts (Magness-Gardiner 2004), we are not aware of any previous discussion of ethics dumping in the archaeological literature (cf. McGill 2014). However, it seems especially relevant to archaeologists from the US, UK, Europe, and Australia and similar locations coming to work in Southeast Asia, where there is often a high disparity between the resources available to visiting and local researchers, and differences between administrative management of ethics in professional contexts.

To illustrate what counts as ethics dumping, here are three examples from recent public health discussions. Srinivasan et al. (2018) describe how known and effective methods of cervical cancer 
screening were withheld from 100,000 women in India in a study design that would not have been allowed in the US, resulting in the death of 254 women. Tangwa et al. (2018) reported on a clinical trial of an Ebola virus vaccine in a sub-Saharan country which had not registered any cases of Ebola. The trial was canceled due to public protest about undue inducements (i.e. financial rewards) to unnecessary exposure to risk of harm from an untested vaccine in a situation where Ebola was not present. Finally, Zhao and Zhang (2018) describe how a US team collecting blood samples from villagers in China were accused of violating research ethics principles by not adequately informing participants and not sharing benefits fairly with their Chinese colleagues.

We can generalise from these examples to define ethics dumping as referring to two situations that we might recognise in archaeology. First, when research participants and/or resources in low- and middle-income countries (LMIC) are exploited intentionally, for instance because research can be undertaken in an LMIC that would be prohibited in a high-income country. Some archaeological examples might include opening an excavation area or volume in the LMIC that might greatly exceed the norms prevalent in a developed country. Similarly, the export of artefacts without Material Transfer Agreements to specify the terms of the loan and return date, or use of digital data without respecting the CARE Principles (Carroll et al. 2020). We may also encounter situations of unskilled labour exploitation where people are paid very little or not at all to work on archaeological sites.

A second situation is when exploitation can occur due to insufficient ethics awareness on the part of the researcher, or low research governance capacity in the host nation (Schroeder et al. 2018). Some examples of this that might be close to home for archaeologists include the involvement of people who have traditional ownership to the land that the archaeological sites are on. In some developed countries it is necessary to directly involve local Indigenous people in archaeological fieldwork to receive a permit for field work. For example, this is required in many places in Australia, but in many areas in Southeast Asia there are no such official requirements. Another case might be coauthorship, where local colleagues might be excluded from the authorship list because of different norms about what qualified contributors to be included as a co-author. For example, the widelyused guidelines of the International Committee of Medical Journal Editors (1985) requires contributors to designated as authors to meet all four of their criteria for authorship: (1) Substantial contributions to the conception or design of the work; or the acquisition, analysis, or interpretation of data for the work; and (2) Drafting the work or revising it critically for important intellectual content; and (3) Final approval of the version to be published; and (4) Agreement to be accountable for all aspects of the work in ensuring that questions related to the accuracy or integrity of any part of the work are appropriately investigated and resolved.

The requirement that authors need to fulfil all four criteria can put local researchers in a difficult position. While only a few people in a research team might make substantial contributions to a manuscript, most manuscript writers know that their local collaborators, among others, made crucial contributions that were essential to enabling the research, and that career progression for local researchers may depend on them becoming co-authors. Strict adherence to these ICMJE guidelines may result in a failure to properly recognise the range of contributions that local researchers make to published output. Adherence to these guidelines varies greatly, and there is substantial inconsistency between researchers regarding the categories of contributions that merit authorship (Patience et al. 2019). 
A solution to this inconsistency, and the associated problem where local researchers may be systematically excluded from authorship, to the detriment of their careers, is a shift from the writercentered model of authorship to a contributorship model with a standardized taxonomy of contributions. An example of a contributorship model is CRediT (Contributor Roles Taxonomy, McNutt et al. 2018). There are fourteen contributor roles in the taxonomy that can be used to describe the typical range of contributions to scholarly publication (Conceptualization, Data curation, Formal Analysis, Funding acquisition, Investigation, Methodology, Project administration, Resources, Software, Supervision, Validation, Visualization, Writing - original draft, Writing review \& editing). Contributor roles can be further qualified as a 'lead', 'equal', or 'supporting' role for each person. The CRediT model is currently in use by more than two dozen scholarly publishers aiming to improve authorship transparency and facilitate formal recognition of a more complete range of contributions to research publications (Holcombe 2019). Use of the CRediT model in Southeast Asian archaeology may improve ethical practice in international collaborations, and we recommend using this taxonomy during discussions about publication planning.

\section{How to avoid ethics dumping in international archaeology?}

How can we translate an awareness of these concepts into an improvement of our practice as archaeologists? International research bristles with ethical challenges and issues that go beyond any simple identification of instances of ethics dumping. This makes it difficult to issue a set of simple prescriptions that will suit all projects. If we return to a concern about the relationships between stakeholders involved in research, perhaps a suitable starting point is to identify relevant stakeholders and invest time to understand their needs and the benefits that are of concern to them. From there we are well-placed to navigate the challenge of finding the intersection of what benefits are desired and meaningful, and what are practical to obtain.

Reflecting on our own modest work in mainland Southeast Asia, we have found three activities to be at this intersection of what is requested by the local communities we work with, what is meaningful to undertake, and what is practical to accomplish with minimal resources. These activities are long established within the US and the UK and similar places (Atalay 2007; Jeppson and Brauer 2007; McAnany and Rowe 2015), but we are not aware of their routine use by the majority of international archaeologists working in Southeast Asia. Indeed, although these activities sound obvious and trite, and only represent a small selection of many possible options, we feel compelled to mention them here because of the number of times we have heard local colleagues ask why visiting researchers do not undertake these activities that they would be expected to do if they were working in their own country. Local archaeologists may find it useful to note the activities described here as a starting point to initiate discussions with international collaborators to address concerns about over-research and ethics dumping.

First, we include in our fieldwork schedule visits to schools located close to the sites at which we work (cf. Corbishley et al. 2008). The aim is to introduce students and teachers to the idea that the remote past is worthy of study, and can be studied systematically and empirically. We bring a selection of artefacts and hand tools for students to handle, and where the facilities permit, we show photos of our fieldwork. We take care to help students understand the difference between research and looting. The exact program of our school visit varies greatly depending on the school we visit and how the teachers can accommodate us. Sometimes we are speaking to every student in the school in an all-school assembly, and on other occasions we are making a brief appearance to a single class. Of course, our preference is to present to as many students as possible in our visits, but we will accept any opportunity to meet with students that the teachers are able to provide, and tailor our presentation to suit the situation. We have found this an excellent opportunity to directly 
communicate the difference between archaeology and looting, and give instructions to students on how they need to report looting to local authorities.

A second activity is pre- and post-fieldwork seminars to relevant local professional communities. These events are important to communicate regular updates on results at the start or end of fieldwork, to share the new findings with the local research community. This also provides a vital opportunity to obtain information from the local community, and to negotiate research priorities with input from the local research community. Professional seminars in the host country are important for reversing the scientific colonialism when foreign researchers are working in a host country, extracting data to be converted into benefits elsewhere (such as degrees, publications, prestige, promotions), that are rarely shared equally with the local community. Scientific colonialism is defined as when the centre of gravity for the acquisition of knowledge about a region is located outside of that region itself (Galtung 1967), and is widely recognised as a core ethical challenge for archaeology (Nicholas and Hollowell 2016; Zimmerman 2001).

A third example of an activity that can help to avoid ethics dumping is short workshops in the host country for training local colleagues in archaeological science. This is an important way to transmit skills across the asymmetrical economic and power relationships that exist among visiting and host researchers. Training activities need to be negotiated in detail to avoid becoming a useless courtesy (Hymes 1972), because simply offering training may not give the local research community access to the contexts where the skills can be used to generate economic and political benefits. With some planning, the workshop can be programmed to match the needs and interests of the local community, and thus be more beneficial. Topics that we have workshopped with our local collaborators in Vietnam and Myanmar include how to do routine archaeological science work reproducibly and transparently using free and open source software such as the R programming language (Marwick 2018, 2017; Marwick et al. 2017).

It is important to note that avoiding ethics dumping is a responsibility that is shared between international and local researchers. One example of our experience of enacting this shared responsibility is in-country cultural sensitivity orientations for field school students coming from the US to Southeast Asia. These are run by the local co-director and provide instructions to students on appropriate behaviour, clothing, and expectations (especially about sensitive topics that are rarely discussed, e.g. personal and intimate relationships) when dealing with local people. Because we often work in remote locations where foreigners are rarely seen, our presence is already a substantial disturbance so it is important to be intentional about minimizing this disturbance. Although we also provide pre-departure briefings to orient students to the local culture, direct instruction from an authoritative local strongly reinforces to international visitors the definitions of ethical behaviours for our specific context.

\section{Future directions}

Future work on other emerging ethical concerns in archaeology should consider the emerging field of geoethics, which is the study of the 'values upon which to base appropriate behavior and practice where human activities intersect the geosphere' (Peppoloni and Di Capua 2015). This extends the scope of ethical concerns beyond artefacts, sites, and people to include the physical environment. Geoethics asks if our use of natural resources is proportionate to the social benefits of our research. This is relevant to international archaeologists working in Southeast Asia because of the carbon 
footprint of the air travel needed to move between home institutions, field locations, and conferences. Reynolds (2018) has called on all archaeologists to take climate change seriously, and immediately change the way we work to reduce carbon emissions. This is especially relevant for international archaeologists working in Southeast Asia because climate change is negatively affecting LMICs more than the home countries of the visiting archaeologists (Hallegatte and Rozenberg 2017). This negative climate effect that international research travel imposes on our host communities increases the need and urgency for those communities to directly benefit from archaeological work. Providing greater local benefits is important to mitigate the climatic effects of scientific colonialism. We anticipate that future work might identify intersections between the remedies for over-research, ethics dumping and geoethical concerns for archaeologists working in Southeast Asia.

A recently emerging urgent concern in the geosciences that is closely related to over-research and ethics dumping is 'helicopter research'. This is defined by van Groenigen and Stoof (2020) as 'where scientists from elsewhere (typically a developed country or non-Indigenous group) conduct research in a developing country or on Indigenous land with the help of local infrastructure and local knowledge, and proceed to publish those results without strong involvement of the local scientists or knowledge owners and without structural improvement of local communities.' In their summary of a special issue of the journal Geoderma devoted to this topic, Groenigen and Stoof identify several actions to avoid helicopter research that are relevant as indicators of future directions for decreasing over-research and ethics dumping. They recommend: planning for the involvement of local experts early on, in the project initiation stage, and highlighting the duty of funding agencies to align priorities with local needs; contributing to an enabling environment for local research, through capacity building and involving students and young researchers, and the supporting development of local laboratory facilities; and creating good support networks to catalyse meaningful collaborations. We find these recommendations highly relevant for archaeologists who are concerned about avoiding over-research and ethics dumping.

\section{Conclusion}

Although over-research and ethics dumping are relatively new terms for archaeology, archaeologists familiar with postcolonial, indigenous, community-based, feminist and related critical approaches to power relationships in archaeological practice will recognise the symptoms of exploitation. However, because much of the literature on these approaches has emerged from a context of North American archaeologists working with American Indigenous communities, its relevance can seem distant and limited to archaeologists working in Southeast Asia. Although both Eastern and Western colonial powers were present in Southeast Asia, most contemporary international archaeologists do not closely identify with these colonial legacies. Thus, we argue that for many researchers, archaeological approaches predicated on decolonisation do not strongly resonate or motivate changes in practice.

Through the introduction of new concepts from public health research that are not strongly bound to a specific colonial legacy, we hope this paper will invigorate discussions of the ethics of foreign archaeologists working in Southeast Asia. Our view is that archaeologists who minimize overresearch and ethics dumping can be highly effective in working towards a more equitable distribution of the benefits of research work. That said, even the simple suggestions we have provided come at an opportunity cost. Days spent visiting schools and giving talks mean fewer days collecting data. The payoff of these activities to the visiting researcher may be undetectable according to the traditional metrics of the academic prestige economy: they will likely not result in 
more publications, citations or grant income. But we have tried to make the case here that they are necessary for an ethical practice of archaeology: we should adopt these norms as part of what defines us as a professional community, distinct from looters, antique dealers and other nonscientific engagements with the archaeological record. The opportunity cost involved in avoiding over-research and ethics dumping is one we should pay to qualify for membership in the professional community of archaeologists working in Southeast Asia for research. We have briefly sketched some concrete activities aimed at fulfilling these necessities, and that hint at the potential for a more humanitarian and just contribution of archaeology to society.

\section{Acknowledgements}

Thanks to the Institute of Archaeology in Hanoi, Vietnam, and the Field School of Archaeology in Pyay, Myanmar, for hosting BM for several visits during which ideas in this paper were developed.

\section{References}

Abbott, AD (2004) Methods of discovery: Heuristics for the social sciences. New York: WW Norton \& Co.

Atalay, S (2012) Community-based archaeology: research with, by, and for indigenous and local communities. Berkeley: University of California Press.

Atalay, S (2007) Global Application of Indigenous Archaeology: Community Based Participatory Research in Turkey. Archaeologies: Journal of the World Archaeological Congress, 3: 249270.

Atalay, S, Clauss, LR, Mcguire, RH and Welch, JR (2016) Transforming archaeology. In: S Atalay, LR Clauss, RH Mcguire \& JR Welch (eds.) Transforming Archaeology: Activist Practices and Prospects. Calnut Creek: Left Coast Press, 7-28.

Carroll, SR, Garba, I, Figueroa-Rodríguez, OL, Holbrook, J, Lovett, R, Materechera, S, Parsons, M, Raseroka, K, Rodriguez-Lonebear, D, Rowe, R, Sara, R, Walker, JD, Anderson, J and Hudson, M (2020) The CARE Principles for Indigenous Data Governance. Data Science Journal, 19(1): 43.

Childe, VG (1933) Is Prehistory Practical? Antiquity, 7: 410-418.

Clark, T (2008) 'We're Over-Researched Here!': Exploring Accounts of Research Fatigue within Qualitative Research Engagements. Sociology, 42: 953-970.

Corbishley, M, Fordham, J, Walmsley, D and Ward, J (2008) Learning Beyond the Classroom: Archaeological Sites and Schools. Conservation and Management of Archaeological Sites, 10(1): 78-92.

Council for International Organizations of Medical Sciences (CIOMS) (2016) International Ethical Guidelines for Health-related Research Involving Humans, Fourth Edition. Geneva: Council for International Organizations of Medical Sciences (CIOMS).

Floridi, L (2019) Translating Principles into Practices of Digital Ethics: Five Risks of Being Unethical. Philosophy \& Technology, 32: 185-193.

Galtung, J (1967) Scientific Colonialism. Transition, 30: 10-15.

Glover, I (1993) Other people's pasts: Western archaeologists and Thai prehistory. Journal of the Siam Society, 81: 45-53.

Glover, IC (2001) Archaeology, Nationalism and Politics in Southeast Asia. Hukay, 3: 37-65. 
Goldstein, L (2000) The potential for future relationships between archaeologists and Native Americans. In: MJ Lynott \& A Wylie (eds.) Ethics in American Archaeology. Washington, D. C.: Society for American Archaeology.

González-Ruibal, A (2019) Ethical Issues in Indigenous Archaeology: Problems with Difference and Collaboration. Canadian Journal of Bioethics, 2(3): 34-43.

González-Ruibal, A, González, PA and Criado-Boado, F (2018) Against reactionary populism: towards a new public archaeology. Antiquity, 92(962): 507-515.

Hallegatte, S and Rozenberg, J (2017) Climate change through a poverty lens. Nature Climate Change, 7(4): 250-256.

Holcombe, AO (2019) Contributorship, not authorship: Use CRediT to indicate who did what. Publications, 7(48)

Holtorf, C (2018) Embracing change: how cultural resilience is increased through cultural heritage. World Archaeology, 50: 639-650.

Hymes, DH (1972) Reinventing anthropology. New York.: Pantheon Books.

International Committee of Medical Journal Editors (1985) Guidelines on authorship. British Medical Journal, 291: 722.

Jeppson, PL and Brauer, G (2007) Archaeology for Education Needs: An Archaeologist and an Educator Discuss Archaeology in the Baltimore Country Public Schools. In: JH Jameson \& S Baugher (eds.) Past Meets Present: Archaeologists Partnering with Museum Curators, Teachers, and Community Groups. New York: Springer, 231-248.

Kajda, K, Marx, A, Wright, H, Richards, J, Marciniak, A, Rossenbach, KS, Pawleta, M, Dries, MHVD, Boom, K, Guermandi, MP, Criado-Boado, F, Barreiro, D, Synnestvedt, A, Kotsakis, K, Kasvikis, K, Theodoroudi, E, Lüth, F, Issa, M and Frase, I (2018) Archaeology, Heritage, and Social Value: Public Perspectives on European Archaeology. European Journal of Archaeology, 21(1): 96-117.

Koen, J, Wassenaar, D and Mamotte, N (2017) The 'over-researched community': An ethics analysis of stakeholder views at two South African HIV prevention research sites. Social Science \& Medicine, 194: 1-9.

Lape, P and Hert, R (2011) Archaeological practice in Timor Leste: Past, present and future. In: J Miksic, GY Goh \& S O'connor (eds.) Rethinking Cultural Resource Management in Southeast Asia: Preservation, Development, and Neglect. London: Anthem Press, 67-87.

Lightfoot, KG, Panich, LM, Schneider, TD, Gonzalez, SL, Russell, MA, Modzelewski, D, Molino, $\mathrm{T}$ and Blair, EH (2013) The Study of Indigenous Political Economies and Colonialism in Native California: Implications for Contemporary Tribal Groups and Federal Recognition. American Antiquity, 78: 89-104.

Lilley, I (2000) Native title and the transformation of archaeology in the postcolonial world. Syndey: University of Sydney.

Magness-Gardiner, B (2004) International conventions and cultural heritage protection. In: Y Rowan \& U Baram (eds.) Marketing Heritage: Archaeology and the Consumption of the Past. Walnut Creek: AltaMira Press, 27-40.

Marwick, B (2017) Computational Reproducibility in Archaeological Research: Basic Principles and a Case Study of Their Implementation. Journal of Archaeological Method and Theory, 24: 424-450.

Marwick, B (2018) R Coding and Modeling. In: SLL Varela (ed.) The Encyclopedia of Archaeological Sciences. Online: John Wily \& Sons, 1-5. 
Marwick, B and Birch, SEP (2018) A Standard for the Scholarly Citation of Archaeological Data as an Incentive to Data Sharing. Advances in Archaeological Practice, 6(2): 125-143.

Marwick, B, Guedes, JDA, Barton, CM, Bates, LA, Baxter, M, Bevan, A, Bollwerk, EA, Bocinsky, RK, Brughmans, T, Carter, AK, Conrad, C, Contreras, DA, Costa, S, Crema, ER, Daggett, A, Davies, B, Drake, BL, Dye, TS, France, P, Fullagar, R, Giusti, D, Graham, S, Harris, MD, Hawks, J, Heath, S, Huffer, D, Kansa, EC, Kansa, SW, Madsen, ME, Melcher, J, Negre, J, Neiman, FD, Opitz, R, Orton, DC, Przystupa, P, Raviele, M, Riel-Salvatore, J, Riris, P, Romanowska, I, Smith, J, Strupler, N, Ullah, II, Vlack, HGV, Vanvalkenburgh, N, Watrall, EC, Webster, C, Wells, J, Winters, J and Wren, CD (2017) Open Science In Archaeology. The SAA Archaeological Record: 1-14.

Marwick, B, Shoocongdej, R, Thongcharoenchaikit, C, Chaisuwan, B, Khowkhiew, C and Kwak, S (2013) Hierarchies of engagement and understanding: Community engagement during archaeological excavations at Khao Toh Chong rockshelter, Krabi, Thailand. In: S Brockwell, S O'connor \& D Byrne (eds.) Transcending the Culture-Nature Divide in Cultural Heritage: Views from the Asia-Pacific Region. Canberra: Australian National University EPress, 129-140.

May, SK, Marshall, M, Sanz, ID and Smith, C (2017) Reflections on the Pedagogy of Archaeological Field Schools within Indigenous Community Archaeology Programmes in Australia. Public Archaeology, 16(3-4): 172-190.

Mcanany, PA and Rowe, SM (2015) Re-visiting the field: Collaborative archaeology as paradigm shift. Journal of Field Archaeology, 40(5): 499-507.

McGill, D (2014) Ethics in Archaeology. In: S C. (ed.) Encyclopedia of Global Archaeology. New York: Springer.

McNutt, MK, Bradford, M, Drazen, JM, Hanson, B, Howard, B, Jamieson, KH, Kiermer, V, Marcus, E, Pope, BK, Schekman, R, Swaminathan, S, Stang, PJ and Verma, IM (2018) Transparency in authors' contributions and responsibilities to promote integrity in scientific publication. Proceedings of the National Academy of Science, 115(11): 2557-2560.

Mrozowski, SA (2012) Pragmatism and the Relevancy of Archaeology for Contemporary Society. In: M Rockman \& J Flatman (eds.) Archaeology in Society: Its Relevance in the Modern World. New York: Springer New York, 239-256.

Nicholas, G and Hollowell, J (2016) Ethical challenges to a postcolonial archaeology: The legacy of scientific colonialism. In: Y Hamilakis \& P Duke (eds.) Archaeology and Capitalism: From Ethics to Politics. Walnut Creek: Left Coast Press, 59-82.

Patience, GS, Galli, F, Patience, PA and Boffito, DC (2019) Intellectual contributions meriting authorship: Survey results from the top cited authors across all science categories. PLoS One, 14(1): e0198117.

Peppoloni, S and Capua, GD (2015) Chapter 1 - The Meaning of Geoethics. In: M Wyss \& S Peppoloni (eds.) Geoethics: Ethical Challenges and Case Studies in Earth Sciences. Amsterdam: Elsevier, 3-14.

Perry, S (2019) The Enchantment of the Archaeological Record. European Journal of Archaeology, 22(3): 354-371.

Pyburn, KA and Wilk, RR (2000) Responsible archaeology is applied anthropology. In: MJ Lynott \& A Wylie (eds.) Ethics in American Archaeology: Challenges for the 1990s. Washington, D.C.: Society for American Archaeology, 71-76. 
Reynolds, N (2018) Decarbonising archaeology. Nature Research Ecology \& Evolution Community. Available at: https://natureecoevocommunity.nature.com/posts/40589cognitive-dissonance-and-archaeological-practice-the-challenge-of-decarbonising-adiscipline [accessed 28 August 2020].

Schaepe, DM, Angelbeck, B, Snook, D and Welch, JR (2017) Archaeology as Therapy: Connecting Belongings, Knowledge, Time, Place, and Well-Being. Current Anthropology, 58(4): 502533.

Schroeder, D, Cook, J, Hirsch, F, Fenet, S and Muthuswamy, V (2018) Ethics Dumping: Introduction. In: D Schroeder, J Cook, F Hirsch, S Fenet \& V Muthuswamy (eds.) Ethics Dumping. Cham: Springer.

Srinivasan, S, Johari, V and Jesani, A (2018) Cervical Cancer Screening in India. In: D Schroeder, J Cook, F Hirsch, S Fenet \& V Muthuswamy (eds.) Ethics Dumping: Case Studies from North-South Research Collaborations. Cham: Springer International Publishing, 33-48.

Sukarieh, M and Tannock, S (2013) On the Problem of Over-researched Communities: The Case of the Shatila Palestinian Refugee Camp in Lebanon. Sociology, 47: 494-508.

Tangwa, GB, Browne, K and Schroeder, D (2018) Ebola Vaccine Trials. In: D Schroeder, J Cook, F Hirsch, S Fenet \& V Muthuswamy (eds.) Ethics Dumping: Case Studies from North-South Research Collaborations. Cham: Springer International Publishing, 49-60.

van Groenigen, JW and Stoof, CR (2020) Helicopter research in soil science: A discussion. Geoderma, 373: 114418.

van den Dries, MH, Boom, KH and Van Der Linde, S (2015) Exploring archaeology's social values for present day society. Analecta Prehistorica Leidensia, 45: 221-234.

Watkins, J (2001) Indigenous archaeology: American Indian values and scientific practice. Walnut Creek: AltaMira Press.

Whitaker, U (1963) The Dangers of Over-Research. Background, 6: 65-70.

Zhao, Y and Zhang, W (2018) An International Collaborative Genetic Research Project Conducted in China. In: D Schroeder, J Cook, F Hirsch, S Fenet \& V Muthuswamy (eds.) Ethics Dumping: Case Studies from North-South Research Collaborations. Cham: Springer International Publishing, 71-80.

Zimmerman, LJ (2001) Usurping Native American Voice. In: T Bray (ed.) The Future of the Past: Archaeologists, Native Americans, and Repatriation. New York: Garland Publishing, 169184. 